\title{
Influence of climatic teleconnections on the temporal isotopic variability as recorded in a firn core from the coastal Dronning Maud Land, East Antarctica
}

\author{
Sushant S Naik ${ }^{1, *}$, Meloth Thamban ${ }^{1}$, A Rajakumar ${ }^{1, \#}$, Witty D'Souza ${ }^{1}$, \\ C M Laluraj ${ }^{1}$ and Arun Chaturvedi ${ }^{2}$ \\ ${ }^{1}$ National Centre for Antarctic and Ocean Research, Vasco-da-Gama, Goa 403 804, India. \\ ${ }^{2}$ Geological Survey of India (Antarctica Division), NH-5P, NIT, Faridabad 121 001, India. \\ \# Presently at the Indian Institute of Technology, Kharagpur 721 302, India. \\ *e-mail: sushant@ncaor.org
}

Ice and firn core studies provide one of the most valuable tools for understanding the past climate change. In order to evaluate the temporal isotopic variability recorded in ice and its relevance to environmental changes, stable isotopes of oxygen and hydrogen were studied in a firn core from coastal Dronning Maud Land, East Antarctica. The annual $\delta^{18} \mathrm{O}$ profile of the core shows a close relation to the El Niño Southern Oscillation (ENSO) variability. The ENSO indices show significant correlation with the surface air temperatures and $\delta^{18} \mathrm{O}$ values of this region during the austral summer season and support an additional influence related to the Southern Annular Mode (SAM). The correlation between the combined ENSO-SAM index and the summer $\delta^{18} \mathrm{O}$ record seems to have been caused through an atmospheric mechanism. Snow accumulation in this region illustrates a decreasing trend with opposite relationships with $\delta^{18} \mathrm{O}$ data and surface air temperature prior and subsequent to the year 1997. A reorganization of the local water cycle is further indicated by the deuterium excess data showing a shift around 1997, consistent with a change in evaporation conditions. The present study thus illustrates the utility of ice-core studies in the reconstruction of past climate change and suggests possible influence of climatic teleconnections on the snow accumulation rates and isotopic profiles of snow in the coastal regions of east Antarctica.

\section{Introduction}

The Antarctic cryosphere forms an integral part of the Earth system and plays a vital role in the dynamic linkages within the global climate change. However, our knowledge of the spatial and temporal complexity of Antarctic climate is extremely poor, mainly due to the limited period of observational and instrumental data of climatic variables from this remote continent. Ice-core records provide one of the most valuable tools for deriving long-term climate data in Antarctica. Among the various proxy variables used for the reconstruction of climate, records of the stable isotopes of oxygen and hydrogen form the backbone of the ice-core research. It is well known that there are linear relationships between stable isotopes of oxygen $\left(\delta^{18} \mathrm{O}\right)$ and hydrogen $(\delta \mathrm{D})$ in ice cores and the temperature at any given precipitation site (Dansgaard 1964). But, factors such as temperature of the source from which moisture evaporated, subsequent cycles of condensation and evaporation, change in moisture source region and seasonality of precipitation make the interpretation of temperature from water isotopes difficult (Jouzel et al 2003; Helsen et al 2006). Some

Keywords. Antarctica; ice cores; teleconnection; isotopes; ENSO; SAM; climate; cryosphere. 
of these factors could be resolved using a second order isotopic parameter called deuterium excess $\left(d=\delta D-8 * \delta^{18} \mathrm{O}\right)$, which is calculated from the combined measurements of $\delta \mathrm{D}$ and $\delta^{18} \mathrm{O}$. This deuterium excess parameter is known to depend on the temperature and relative humidity of the evaporative source (Ciais et al 1995; Jouzel et al 2003).

On an interannual to decadal timescale, tropospheric Antarctic circulation is known to be influenced by the Southern Annular Mode (SAM) and/or El Niño Southern Oscillation (ENSO) (Kwok and Comiso 2002a; Bertler et al 2006; Fogt and Bromwich 2006; Gregory and Noone 2008; Divine et al 2009). The SAM is the principal extra-tropical atmospheric circulation mode in the southern hemisphere and represents the fluctuation in strength of the circumpolar vortex, the belt of tropospheric westerlies surrounding the Antarctic continent. The ENSO on the other hand is characterised by a pattern of warm and cold sea surface temperature anomalies in the central and eastern equatorial Pacific with coupled atmospheric changes, which extend to even Antarctica (Turner 2004). The changes in ENSO are known to affect the SAM, but in a highly nonlinear way (Kwok and Comiso 2002b). Combined, the two forcings have the potential to partially offset or enhance their influence on each other and the Southern Hemisphere as a whole (Bertler et al 2006).

Snow/ice records from Antarctica were widely used to understand the recent climate variability and the various linking mechanisms (Hanna 2001; Kwok and Comiso 2002b; Fogt and Bromwich 2006; Gregory and Noone 2008; Divine et al 2009). However, only a few studies have been conducted on coastal regions of Dronning Maud Land (Isaksson et al 1996; Nijampurkar et al 2002; Thamban et al 2006; Masson-Delmotte et al 2008; Divine et al 2009). In this study, we provide a preliminary evaluation of the temporal isotopic variability from a firn core from coastal region of Dronning Maud Land (DML) and its relation to the available meteorological records as well as the possible influences from climatic teleconnections related to ENSO and SAM in this part of Antarctica.

\section{Samples and techniques}

During the 25th Indian Scientific Expedition to Antarctica (2005-06), a $65 \mathrm{~m}$ long ice core (IND25/B5) was drilled from the continental ice sheet at $71.34^{\circ} \mathrm{S}$ and $11.59^{\circ} \mathrm{E}$, in the coastal Dronning Maud Land (elevation of $\sim 1300 \mathrm{~m}$ ) (figure 1). The core site is influenced by katabatic winds and is characterised by high snow accumulation rates. Due to steep gradient in slope and high mountains to the south of the core site, the katabatic wind intensity is much higher at the core site, compared to the low altitude site of Russian station Novolazarevskaya (Novo). Based on the Ground Penetrating Radar (GPR) survey conducted by us as well as based on the information available (Anschütz et al 2007), the core site is not affected by any flow or topographic effects. Annual mean temperature at the core site is $\sim-20^{\circ} \mathrm{C}$ and the accumulation rate in the area is in the order of $\sim 0.25$ metre water equivalent per year $\left(\mathrm{m} \mathrm{w}\right.$. e. $\left.\mathrm{a}^{-1}\right)$ (Anschütz et al 2007). Drilling was conducted using an electromechanical system (diameter $\sim 10 \mathrm{~cm}$ ) during the austral summer. The cores were packed in LDPE (low density polyethylene) containers and shipped under refrigeration $\left(-20^{\circ} \mathrm{C}\right)$ in EPP (expanded polypropylene) insulated containers to Goa, India. The ice core samples have been archived at $-20^{\circ} \mathrm{C}$ at the National Centre for Antarctic and Ocean Research (NCAOR) cold-room facility and processed at $-15^{\circ} \mathrm{C}$. The sub-sampling of the ice core was done at $5 \mathrm{~cm}$ intervals using bandsaw machines.

Stable isotope ratios were measured by a dual inlet, 'Isoprime' Isotope Ratio Mass Spectrometer, from GV instruments (UK). Oxygen isotope analysis was made using the method of equilibration with $\mathrm{CO}_{2}$ gas (Epstein and Mayeda 1953). For hydrogen isotope analysis, method of $\mathrm{H}_{2}-\mathrm{H}_{2} \mathrm{O}$ equilibration using platinum catalyst was used (Coplen 1991). All measurements were made against international standards: Vienna Standard Mean Ocean Water (VSMOW) and Standard Light Antarctic Precipitation (SLAP) (Coplen 1996) in duplicates. The isotopic composition is expressed in per mil $(\% 0)$ deviation from VSMOW standard. The external precision $(1 \sigma)$ using a laboratory standard (CDML1) on oxygen and hydrogen is $\pm 0.05 \%$ and $\pm 0.77 \%$, respectively $(n=30)$. The precision of deuterium excess estimation based on the precision of oxygen and hydrogen stated above estimates to $\pm 0.87 \%$.

The age control for the firn core is based on the annual layer determination by counting summer peaks (maxima) of $\delta^{18} \mathrm{O}$ after a five-point smoothing to reduce the background noise. The high sampling resolution ensured that each annual accumulation layer is represented on average by thirteen $\delta^{18} \mathrm{O}$ measurements. This dating was supported by the $\mathrm{nssSO}_{4}^{2-}$ (non-sea salt sulphate) peak related to the well known Pinatubo (AD 1991) eruption. The uppermost $13.75 \mathrm{~m}$ of the core is dated back to 1986 with an error of $\pm 1 \mathrm{yr}$ (figure 2). We discuss only the $13.75 \mathrm{~m}$ section of this core as it corresponds to two decades covering well-recorded intense ENSO events: 1986-87, 


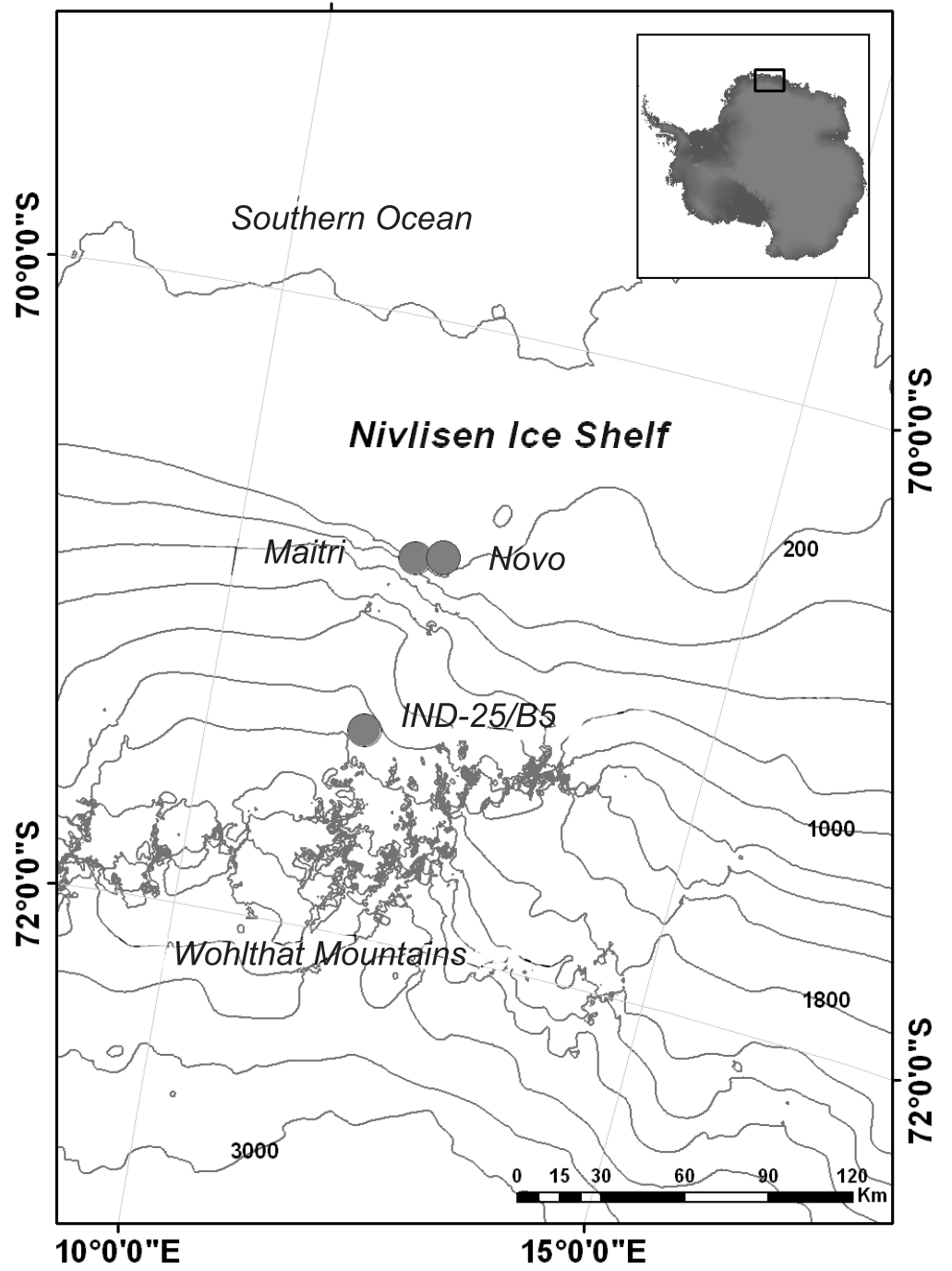

Figure 1. Study area showing the ice core location in the coastal Dronning Maud Land in East Antarctica. The stations 'Maitri' and 'Novolazarevskaya' are situated on an ice-free strip within close proximity to one another.

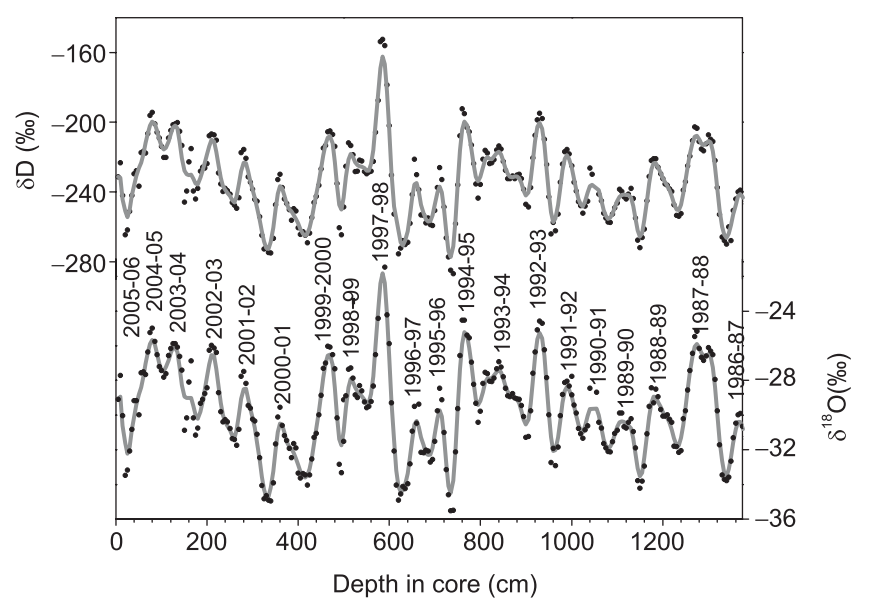

Figure 2. The $\delta \mathrm{D}$ and $\delta^{18} \mathrm{O}$ profiles from core IND-25/B5. The measured ' $\delta$ ' values are represented by black dots and the grey lines represent the running average of the profiles. Summer peaks in the $\delta^{18} \mathrm{O}$ record are used as age markers and labeled accordingly.
1991-92, 1997-98 and 2002-03 during summer period and in 1987, 1991, 1993, 1994, 1997 and 2002 during winter. The NCEP/NCAR data is also robust for these two decades (Turner 2004). Annual $\delta^{18} \mathrm{O}$ values are calculated from the unsmoothed data coincident with the calendar year. With annual mean air temperature as low as $\sim-20^{\circ} \mathrm{C}$, summer melting is absent in this region. Visual observations on a light table also revealed the absence of any melt features in the ice core. Additionally, the high amplitude seasonality in the oxygen isotope data suggests that the remixing of the snow layers is at minimum.

The Southern Oscillation Index (SOI), Niño 4 index and SAM index data have been obtained from NOAA's Climate Prediction Center. Relationships between SOI, Niño 4, SAM indices and surface air temperature at the core site have been derived using the NCEP/NCAR (National 


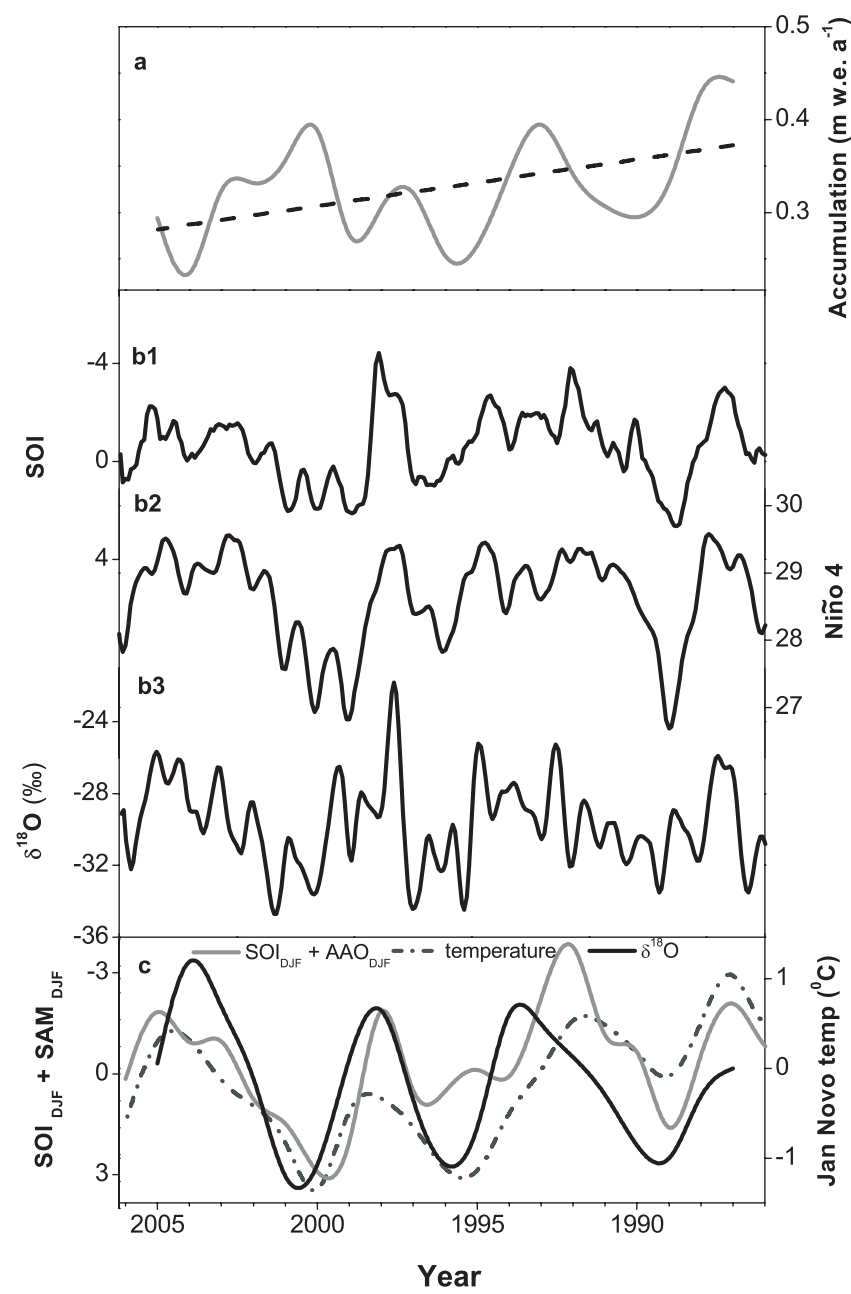

Figure 3. (a) Annual accumulation rates $\left(\mathrm{m}\right.$ w. e. $\mathrm{a}^{-1}$ ) estimated from core IND-25/B5 for the period of study. The black dashed line indicates the long-term trend; (b) Relationships between the SOI, Niño 4 index and the $\delta^{18} \mathrm{O}$ record for the last two decades; (c) Annual mean $\delta^{18} \mathrm{O}$ data in comparison with a joint index of Southern Oscillation and Southern Annular Mode for the austral summer season $\left(\mathrm{SOI}_{\mathrm{DJF}}+\mathrm{SAM}_{\mathrm{DJF}}\right)$ and with the January temperature record from the 'Novo' station.

Centre for Environmental Prediction/National Center for Atmospheric Research) reanalysis data (Kalnay et al 1996). The Russian 'Novo' station temperature and relative humidity record were obtained from the READER (REference Antarctic Data for Environmental Research) database (Turner 2004).

\section{Results and discussion}

The oxygen $\left(\delta^{18} \mathrm{O}\right)$ and hydrogen $(\delta \mathrm{D})$ isotopic records from the core IND-25/B5 are presented in figure 2. The $\delta^{18} \mathrm{O}$ values show clear summer maxima and winter minima throughout the core with values ranging from $-20 \%$ to $-35 \%$ with a mean of $-29.68 \%$. Annual amplitude of $\delta^{18} \mathrm{O}$ record ranges from $1.9 \%$ to $14.5 \%$ with an average of $5.62 \%$. In comparison, another firn core from the coastal DML (location: $71.08^{\circ} \mathrm{S}$ and $11.6^{\circ} \mathrm{E}$; elevation of $\sim 1000 \mathrm{~m}$ a.s.l) showed $\delta^{18} \mathrm{O}$ values between $-20 \%$ and $-38 \%$ for the period 1968 to 2003 (Anschütz et al 2007). Studies from the western DML region have also reported comparable $\delta^{18} \mathrm{O}$ values ranging from $-23.2 \%$ to $-35.9 \%$ at coastal locations (Isaksson et al 1996). The comparability of these records with the present data confirms the quality of the proxy data presented here. The $\delta \mathrm{D}$ values show a similar variation to that of $\delta^{18} \mathrm{O}$, ranging from $-152 \%$ to $-287 \%$ with a mean value of $-234 \%$ (see figure 2). The isotopic composition of worldwide freshwater sources are defined by the meteoric water line, $\delta \mathrm{D}=8 * \delta^{18} \mathrm{O}+10$ (Craig 1961). Based on the present dataset, the relationship between the oxygen and hydrogen isotopes fits to the linear line defined by $\delta \mathrm{D}=8.2 * \delta^{18} \mathrm{O}+10.1$ $(r=0.98 ; n=273)$.

The average annual accumulation rate at the core site calculated based on the seasonal peaks in the $\delta^{18} \mathrm{O}$ record and density of firn at the respective section in the core, is of the order of $0.33 \mathrm{~m} \mathrm{w}$. e. $\mathrm{a}^{-1}$ (metre water equivalent per year), ranging from a minimum of $0.19 \mathrm{~m}$ w.e. $\mathrm{a}^{-1}$ up to $0.46 \mathrm{~m}$ w.e. $\mathrm{a}^{-1}$ (figure $3 \mathrm{a}$ ). Such high accumulation rates are comparable to those reported by Anschütz et al (2007) for this region. The high accumulation variability is also well documented in other coastal areas of DML and is caused presumably due to the variations in cyclonic activities (Van Lipzig et al 1999). The overall accumulation trend shows a decrease during the past two decades (figure 3a), which is in agreement with other cores from DML (Kaczmarska et al 2004).

To compare the firn core data with actual meteorological measurements, monthly temperature data from the 'Novo' station $\left(70.77^{\circ} \mathrm{S}\right.$ and $11.83^{\circ} \mathrm{E}$; elevation: $102 \mathrm{~m}$ a.s.l) close to Indian station 'Maitri' in the coastal DML is used (see figure 1). Though the coring site is situated inland $(\sim 65 \mathrm{~km})$ from the 'Novo' station and at higher altitude, the interannual temperature amplitude would be broadly representative of the entire region, including the core site. Annual $\delta^{18} \mathrm{O}$ values and mean annual temperature from 'Novo', show poor correlation suggesting that other factors do influence the $\delta^{18} \mathrm{O}$ and $\delta \mathrm{D}$ records in this region. Since isotopic content of snowfall in the coastal Antarctic sites is sensitive to factors such as poleward moving airmasses, variations in local moisture sources and sea ice extent (Isaksson and Karlén 1994; Noone and Simmonds 2004) in addition to the temperature, and since the precipitation is largely dependent on the cyclonic storm activity, direct interpretation of oxygen isotopes in terms of temperature is not realistic. 


\subsection{Relationships between the stable isotope records, ENSO and SAM}

Though the ENSO is known to occur in the tropical Pacific, its signals are recorded in other sectors of Antarctica. This teleconnection occurs through the Pacific South American pattern (PSA), which represents a series of positive and negative geopotential height anomalies initiated from tropical convection and extending from central equatorial Pacific to Australia, South Pacific near Antarctica, South America and then bending northwards towards Africa (Turner 2004). During the ENSO events, the PSA pattern gives rise to geopotential height anomalies over the AmundsenBellingshausen seas and the Weddell Sea region. This phenomenon termed as the Antarctic Dipole is seen in out-of-phase relationship in sea ice and surface temperature anomalies in South Pacific and South Atlantic (Yuan 2004). Since the present ice core is located in the Atlantic sector, it is possible to examine the presence of ENSO signals. The SOI is the normalized pressure difference between Tahiti $\left(17.5^{\circ} \mathrm{S}, 149.6^{\circ} \mathrm{W}\right)$ and Darwin $\left(12.4^{\circ} \mathrm{S}\right.$, $130.9^{\circ} \mathrm{E}$ ) and is used to monitor the ENSO.

The $\delta^{18} \mathrm{O}$ profile of the firn core shows resemblance to the SOI for the period from 1986 to 2006 especially at the 1997-1998 El Niño peak with a significant negative relationship $(r=-0.36$, $n=21 ; 95 \%$ level) (figure 3(b1), 3(b3)). Since a negative SOI indicates warm ENSO event (El Niño) and a positive SOI indicates a cool ENSO event (La Niña), the $\delta^{18} \mathrm{O}$ data reveals less negative values during warm ENSO events and vice versa. A similar relationship to ENSO events is demonstrated in an ice core study from eastern DML (Divine et al 2009). During the El Niño events, the central and eastern tropical Pacific waters warm up, causing the SSTs in the Pacific to rise. The Niño 4 index is the SST record from the central Tropical Pacific region from $5^{\circ} \mathrm{N}$ to $5^{\circ} \mathrm{S}$ and $160^{\circ} \mathrm{E}$ to $150^{\circ} \mathrm{W}$ and also used to monitor the ENSO. In order to supplement the relationship of the $\delta^{18} \mathrm{O}$ to SOI, we also examined the relationship between $\delta^{18} \mathrm{O}$ and the Niño 4 index. It is found that the Niño 4 index has a close positive relation with the $\delta^{18} \mathrm{O}$ profile of the firn core presented here $(r=0.45$, $n=21$; significant at $97.5 \%$ level) (figure $3(\mathrm{~b} 2)$, $3(\mathrm{~b} 3)$ ). The relationship between $\delta^{18} \mathrm{O}$ and SOI and Niño 4 does not show any lead/lag within the uncertainty of the age model $( \pm 1 \mathrm{yr})$.

In order to better understand the observed relationship between $\delta^{18} \mathrm{O}$ record and the ENSO indices, relationships between the surface air temperature at the study region and Niño 4 index were examined using the NCEP/NCAR reanalysis data. Since the austral spring (September-November;
SON) and summer (December-February; DJF) are the peak seasons for ENSO, seasonal correlations were examined for these periods. A statistically significant (95\% level) correlation was found between the austral summer surface air temperature at the core site and austral summer Niño 4 with ' $r$ ' value better than $0.4(n=21)$. A similar, negative correlation (95\% level) was found between the surface air temperature and SOI during austral summer.

Another hemisphere-wide atmospheric phenomenon influencing the Antarctic region is the Southern Annular Mode (SAM). The SAM contributes to $\sim 35 \%$ of variance in sea level pressure or geopotential height on a large range of time scales (Marshall 2003). A positive SAM index indicates lower pressure over Antarctica and higher pressure at mid-latitudes. During times of high SAM index, most of east Antarctica experiences a cooling through the strengthening of westerlies, while the Antarctic Peninsula experiences a warming (Kwok and Comiso 2002b). Since SAM is known to influence the entire Antarctica, its probable signature in the isotopic record was evaluated using the NCEP/NCAR reanalysis data. The SAM shows a statistically significant (95\% level) negative correlation with the surface air temperature in the study region during austral summer with $r=-0.5(n=21)$. This finding is indicative of the influence of SAM and is consistent with the general observation that negative phase of SAM leads to higher air temperatures at east Antarctica.

Recent studies also suggested that the ENSO and SAM can occur in phase, leading to a strong teleconnection to Antarctica (Bertler et al 2006; Fogt and Bromwich 2006; Gregory and Noone 2008; Divine et al 2009). Using the present isotopic record as well as the NCEP/NCAR reanalysis data, it is found that both SOI and SAM show a negative relationship to surface air temperature of the core site during the austral summer (DJF) season for the period discussed here (1986-2006). The connections between the ENSO and SAM appear only in the season when the ENSO phases reach their mature stage and forcing is particularly strong and were found to be significant in the 1980s and 1990s (Fogt and Bromwich 2006). The SOI and SAM indices are also known to be positively correlated since 1979 during the SON and DJF seasons (Bertler et al 2006; Fogt and Bromwich 2006). A significant relationship has been noted wherein high tropical Pacific SSTs lead to negative phases of the SAM (Fogt and Bromwich 2006), giving further credence to the significant positive correlation seen here between the SOI and SAM during summer season.

In order to assess the combined influence of SOI and SAM on the coastal DML summers, 
the summer SAM and the summer SOI were added together and their combined index $\left(\mathrm{SOI}_{\text {DJF }}+\mathrm{SAM}_{\text {DJF }}\right)$ was compared with the summer (January) temperature at 'Novo' station and with the $\delta^{18} \mathrm{O}$ record over the common time period of 1986-2006 (figure 3c). The correlation between $\mathrm{SOI}_{\mathrm{DJF}}+\mathrm{SAM}_{\mathrm{DJF}}$ and 'Novo' January temperatures results in a weak negative relation$\operatorname{ship}(r=-0.34, n=21)$ and that of the January temperatures with annual mean $\delta^{18} \mathrm{O}$ with a weak positive correlation of $r=0.22(n=21)$. Further, we calculated the correlation of annual $\delta^{18} \mathrm{O}$ with that of the summer maxima and the winter minima $\delta^{18} \mathrm{O}$ values. The relationship between annual $\delta^{18} \mathrm{O}$ and the summer $\delta^{18} \mathrm{O}$ values is significantly positive with $r=0.76(n=21$, significant at $>99.5 \%$ level) and stronger than that with winter $\delta^{18} \mathrm{O}$ values, suggesting that the summer $\delta^{18} \mathrm{O}$ values dominate the annual oxygen isotopic record. This relationship, along with the significant correlation of SOI, Niño 4 and SAM indices with surface air temperatures as demonstrated earlier in this study, implies that the annual oxygen isotopic content is more influenced by the summer temperatures at the core site, which in turn responds to the joint forcing of SOI and SAM during austral summers. The results from this study are consistent with that of Divine et al (2009), which demonstrates that the Atlantic sector is coupled to the central Pacific and hence to ENSO through the SAM.

The SAM and ENSO teleconnection to Antarctica are known to be established through an atmospheric mechanism and are observed in the $500 \mathrm{mb}$ geopotential height fields (Fogt and Bromwich 2006). To understand the atmospheric circulation anomalies over Antarctica during ENSO events, anomaly composites of $500 \mathrm{mb}$ geopotential height, sea level pressure and surface zonal winds were calculated using NCEP/NCAR data for strong El Niño minus La Niña years (1987, 1992, 1998, 2003, -1989,-1996, -2000) (figure 4a, $\mathrm{b}$ and $\mathrm{c}$ ). The composite diagrams are plotted for the region south of $50^{\circ} \mathrm{S}$ and between $90^{\circ} \mathrm{W}$ and $90^{\circ} \mathrm{E}$. The $500 \mathrm{mb}$ geopotential height shows a high above the Antarctic continent and the circumpolar trough relative to the region north of $70^{\circ} \mathrm{S}$ (figure 4a). The sea level pressure is also higher over the continent and lower over the region north of the circumpolar trough (figure 4b). This would lead to a decrease in pressure gradient and hence a weakening of the westerlies at $\sim 60^{\circ} \mathrm{S}$. This feature is well captured by the surface zonal wind composites which show weakened westerlies (figure 4c). The anomaly composites suggest a predominant negative phase of the SAM and SOI during austral summer. It has been shown that the Pacific SST's modulate the SAM during this season and cause weakening of the SAM during
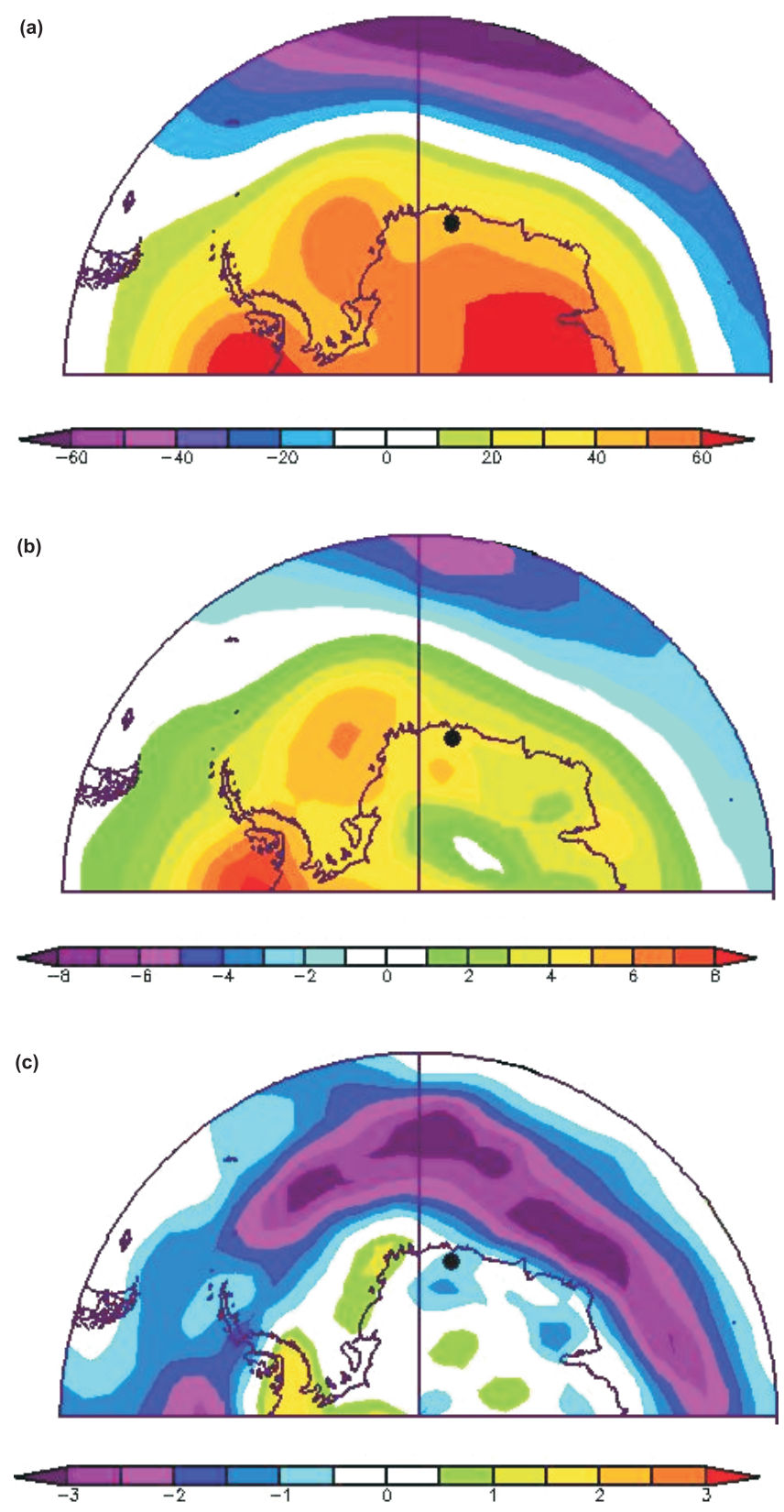

Figure 4. NCEP/NCAR anomaly composites for El Niño minus La Niña events $(1987,1992,1998,2003,-1989,-1996$, -2000) during the austral summer season for: (a) $500 \mathrm{mb}$ geopotential height $(\mathrm{m})$; (b) sea level pressure (mb); and (c) surface zonal winds $(\mathrm{m} / \mathrm{s})$.

strong El Niño periods (Zhou and Yu 2004; Fogt and Bromwich 2006). The Weddell Sea is a location for cyclogenesis throughout the year (Noone et al 1999). During ENSO periods, as a part of the PSA pattern a stronger low pressure develops over the Weddell Sea (Noone et al 1999). Back trajectory studies carried out by us using the National Institute for Polar Research trajectory model, NITRAM (Tomikawa and Sato 2005), indicates that the cyclonic circulation of the Weddell Sea indeed extends its eastern branch over the DML. 


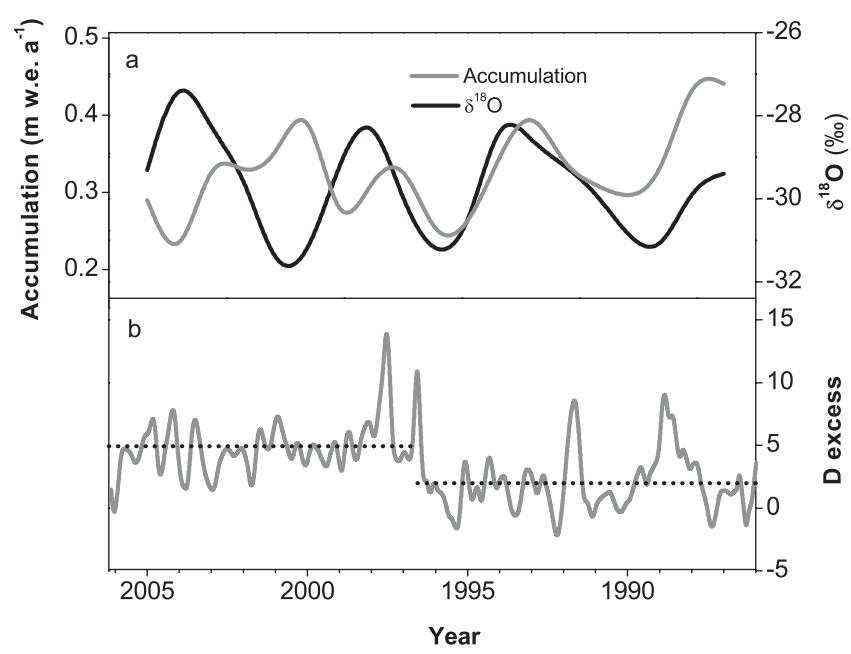

Figure 5. (a) Annual mean $\delta^{18} \mathrm{O}$ record in comparison with the annual accumulation rate profile from core IND-25/B5 and (b) deuterium excess record for the firn core displaying large fluctuations and a shift before and after the year 1997 indicated by horizontal dashed lines.

The ENSO composites as shown earlier reveal weakened westerlies during the negative phase of SOI and SAM. Hence during warm ENSO periods, the weakening of westerlies and the cyclonic circulation allow warm atmospheric airmass from lower latitudes to advect further inland over Antarctica causing rise in surface air temperatures during the austral summer.

\subsection{Variability in accumulation rates, temperature and deuterium excess}

It was suggested that there exists a strong positive relationship between snow accumulation rates and temperature in Antarctica (Masson-Delmotte et al 2008). To assess the relation between these parameters at our study site, records of accumulation and $\delta^{18} \mathrm{O}$ (representing summer temperature in this case) for the past two decades were examined (figure 5a). The parameters reveal similar variation up to the 1997 period, beyond which they show an opposite relationship. Such contradictory changes have been noted for the western DML and were credited to the seasonality in precipitation, changing trajectories of cyclones and changing moisture sources (Isaksson et al 1996).

Moisture source region for the DML is situated at the South Atlantic Ocean anywhere from $30^{\circ} \mathrm{S}$ to $60^{\circ} \mathrm{S}$ (Ciais et al 1995; Reijmer and Van den Broeke 2001). Changing moisture sources and changes in relative humidity of the source region could be understood from the deuterium excess parameter $\left(d=\delta \mathrm{D}-8 * \delta^{18} \mathrm{O}\right)$ defined as a deviation from the meteoric water line (Dansgaard 1964). In the present study, deuterium excess values are highly varying throughout the core shifting between $-2 \%$ and $14 \%$. The D excess record reveals a shift in D excess values before and after the year 1997, corresponding to similar changes in the accumulation and $\delta^{18} \mathrm{O}$ record (figure $5 \mathrm{~b}$ ). Values prior to the year 1997 show an average D excess of 2\%, whereas after the year 1997 the average is higher with a value of $\sim 5 \%$. This is consistent with a possible change in evaporation conditions prior and after the year 1997. However, we are unable to provide definitive reason for this change and warrant a detailed reconstruction of sea ice conditions and back trajectories in the past.

In order to understand to what extent the D excess proxy accounts for the relative humidity, which is a measured parameter and available from the 'Novo' station, the relationship was examined between annual relative humidity record from 'Novo' and the annual D excess record of the firn core (not shown). The significant negative correlation $(r=-0.4, n=19$; significant at $95 \%$ level) between the two parameters suggests that the $\mathrm{D}$ excess record of the firn core is influenced by the relative humidity changes in the coastal DML region. Such a negative relationship between deuterium excess and relative humidity are also supported by earlier studies (e.g., Merlivat and Jouzel 1979). However, such a relationship is not adequate to explain the relative humidity at the moisture source region.

The D excess record exhibits few spikes synchronous with some of the major ENSO events during the last two decades, viz., El Niño events of 1991-92 and 1997-98. Cyclonic activities are known to increase during the ENSO events and these cyclonic activities have large influence on the air trajectories (Noone et al 1999). The isotopic composition of moisture can deviate from the mean state during cyclones and it was suggested that an increase in the advection height of an air trajectory will increase the $D$ excess value of the vapour and hence the precipitation (Helsen et al 2006). Wind speed is also known to influence the $\mathrm{D}$ excess, though in a non-linear way (Ciais et al 1995). D excess may therefore, significantly change during the cyclonic events associated with ENSO. However, the 1988-89 peaks do not correspond to any of the ENSO event during the last two decades. In order to further evaluate the relationships between the accumulation rates, D excess and ENSO, detailed study of a longer ice-core record is necessary.

\section{Conclusions}

The $\delta^{18} \mathrm{O}$ record from the firn core from the coastal DML region covering a period of past two decades reveals a significant relationship with the SOI and 
Niño 4 index, indicating the influence of ENSO in this region. The relationship between $\delta^{18} \mathrm{O}$ and SOI is negative and that between $\delta^{18} \mathrm{O}$ and the Niño 4 index is positive, suggesting that the warm ENSO (El Niño) events lead to higher surface air temperatures in coastal Dronning Maud Land during the austral summer. The SAM also shows a significant negative relation to the surface air temperatures in this region during summer season. It is suggested that the surface air temperature in this region in the past was influenced by the joint forcing of ENSO and SAM during the austral summer which in turn influenced the annual $\delta^{18} \mathrm{O}$ variations. The coupling between ENSO and SAM seems to be caused by the weakening in westerlies surrounding the Antarctic continent. The exact mechanism controlling the coupling between the two modes needs further investigation and records extending for longer time periods are critical in understanding the temporal stability of this relationship.

Snow accumulation rates for the last two decades in the study area show a significant decreasing trend. The correlation between $\delta^{18} \mathrm{O}$ and accumulation rates before the year 1997 and the anticorrelation observed since then appears to be associated with a shift in the deuterium excess record. It is seen that large variations in D excess are generally associated with major El Niño events. This study thus serves to indicate the importance of the circulation changes in determining the temporal variability of isotopes and surface temperature anomalies.

\section{Acknowledgements}

We thank the Ministry of Earth Sciences (New Delhi) and Director, NCAOR for their support. The authors thank B L Redkar (NCAOR) for isotopic analysis and P C George (GSI) for the field work. The leader and team members of the Indian Scientific Expedition to Antarctica during 2005-06 are thanked for their co-operation.

\section{References}

Anschütz H, Eisen O, Oerter H, Steinhage D and Scheinert M 2007 Investigating small-scale variations of the recent accumulation rate in coastal Dronning Maud Land, East Antarctica; Ann. Glaciol. 46 14-21.

Bertler N A N, Naish T R, Kiphstuhl S, Barrett P J, Mayewski P A and Kreutz K J 2006 The effects of joint ENSO-Antarctic oscillation forcing on the McMurdo Dry Valleys, Antarctica; Ant. Sci. 18(4) 507-514.

Ciais P, White J W C, Jouzel J and Petit J R 1995 The origin of present-day Antarctic precipitation from surface deuterium excess data; J. Geophys. Res. 100(D9) $18,917-18,927$.
Coplen T B 1991 Improvements in the gaseous hydrogenwater equilibration technique for hydrogen isotope ratio analysis; Anal. Chem. 63 910-912.

Coplen T B 1996 New guidelines for reporting stable hydrogen, carbon and oxygen isotope-ratio data; Geochim. Cosmochim. Acta. 60 3359-3360.

Craig H 1961 Isotopic variations in meteoric waters; Science 133 1702-1703.

Dansgaard W 1964 Stable isotopes in precipitation; Tellus 16 436-468.

Divine D V, Isaksson E, Kaczmarska M, Godtliebsen F, Oerter H, Schlosser E, Johnsen S J, van den Broeke M and van de Wal R S W 2009 Tropical Pacific-high latitude south Atlantic teleconnections as seen in $\delta^{18} \mathrm{O}$ variability in Antarctic coastal ice cores; J. Geophys. Res. 114 D11112, doi: 10.1029/2008JD010475.

Epstein S and Mayeda T 1953 Variations of $\mathrm{O}^{18}$ contents of waters from natural sources; Geochim. Cosmochim. Acta. 4213.

Fogt R L and Bromwich D H 2006 Decadal variability of the ENSO teleconnection to the high-latitude south Pacific governed by coupling with the southern annular mode; J. Climate 19 979-997.

Gregory S and Noone D 2008 Variability in the teleconnection between the El Niño-Southern Oscillation and West Antarctic climate deduced from West Antarctic ice core isotope records; J. Geophys. Res. 113 D17110, doi: 10.1029/2007JD009107.

Hanna E 2001 Anomalous peak in Antarctic sea-ice area, winter 1998, coincident with ENSO; Geophys. Res. Lett. 28(8) 1595-1598.

Helsen M M, van de Wal R S W, van den Broeke M R, Masson-Delmotte V, Meijer H A J, Scheele M P and Werner M 2006 Modeling the isotopic composition of Antarctic snow using backward trajectories: Simulation of snow pit records; J. Geophys. Res. 111 D15109, doi: 10.1029/2005JD006524.

Isaksson E and Karlén W 1994 Spatial and temporal patterns in snow accumulation, western Dronning Maud Land, Antarctica; J. Glaciol. 40(135) 399-409.

Isaksson E, Karlén W, Gundestrup N, Mayewski P, Whitlow S and Twickler M 1996 A century of accumulation and temperature changes in Dronning Maud Land, Antarctica; J. Geophys. Res. 101(D3) 7085-7094.

Jouzel J, Vimeux F, Caillon N, Delaygue G, Hoffmann G and co-authors 2003 Magnitude of isotope/temperature scaling for interpretation of central Antarctic ice cores; J. Geophys. Res. 108(D12) 4361.

Kaczmarska M, Isaksson E, Karlöf L, Winther J-G, Kohler J, Godtliebsen F, Ringstad Olsen L, Hofstede C M, Van den Broeke M R, Van de Wal R S W and Gundestrup N 2004 Accumulation variability derived from an ice core from coastal Dronning Maud Land, Antarctica; Ann. Glaciol. 39 339-345.

Kalnay E and co-authors 1996 The NCEP/NCAR 40-years reanalysis project; Bull. Am. Meteor. Soc. 77 437-471.

Kwok R and Comiso J C 2002a Southern Ocean climate and sea ice anomalies associated with the southern oscillation; J. Climate 15 487-501.

Kwok R and Comiso J C 2002b Spatial patterns of variability in Antarctic surface temperature: Connections to the southern hemisphere annular mode and the southern oscillation; Geophys. Res. Lett. 29 doi: 10.1029/2002GL015415.

Marshall G J 2003 Trends in the southern annular mode from observations and reanalyses; J. Climate 16 4134-4143.

Masson-Delmotte V and others 2008 A review of Antarctic surface snow isotopic composition: Observations, 
atmospheric circulation and isotopic modeling; J. Climate 21 3359-3387.

Merlivat L and Jouzel J 1979 Global climatic interpretation of the deuterium-oxygen 18 relationship for precipitation; J. Geophys. Res. 84(C8) 5029-5033.

Nijampurkar V N, Rao D K, Clausen H B, Kaul M K and Chaturvedi A 2002 Records of climatic changes and volcanic events in an ice core from Central Dronning Maud Land (East Antarctica) during the past century; Proc. Indian Acad. Sci. (Earth Planet. Sci.) 111 39-49.

Noone D, Turner J and Mulvaney R 1999 Atmospheric signals and characteristics of accumulation in Dronning Maud Land, Antarctica; J. Geophys. Res. 104(D6) 19,191-19,211.

Noone D and Simmonds I 2004 Sea ice control of water isotope transport to Antarctica and implications for ice core interpretation; J. Geophys. Res. 109 D07105, doi: 10.1029/2003JD004228.

Reijmer C H and Van den Broeke M R 2001 Moisture source of precipitation in Western Dronning Maud Land, Antarctica; Ant. Sci. 13(2) 210-220.
Thamban M, Chaturvedi A, Rajakumar A, Naik S S, D'Souza W, Singh A, Rajan S and Ravindra R 2006 Aerosol perturbations related to volcanic eruptions during the past few centuries as recorded in an ice core from the Central Dronning Maud Land, Antarctica; Curr. Sci. 91(9) 1200-1207.

Tomikawa Y and Sato K 2005 Design of NIPR trajectory model; Polar Meteorol. Glaciol. 19 120-137.

Turner J 2004 Review: The El Niño-Southern Oscillation and Antarctica; Int. J. Climatol. 24 1-31.

Van Lipzig N P M, Van Meijgaard E and Oerlemans J 1999 Evaluation of a regional atmospheric model using measurements of surface heat exchange processes from a site in Antarctica; Mon. Wea. Rev. 127(9) 1994-2001.

Yuan X 2004 ENSO-related impacts on Antarctic sea ice: A synthesis of phenomenon and mechanisms; Ant. Sci. 16(4) 415-425, doi: 10.1017/S0954102004002238.

Zhou T and Yu R 2004 Sea-surface temperature induced variability of the Southern Annular Mode in an atmospheric general circulation model; Geophys. Res. Lett. 31 L24206, doi: 10.1029/2004GL021473. 